\title{
Molecular Immune Pathogenesis and Diagnosis of COVID-19 - A Review
}

\section{IJCRR}

Section: Healthcare

Sci. Journal Impact

Factor: 6.1 (2018)

ICV: 90.90 (2018)

(c) (7) (3)

Copyright@IJCRR

\section{Rithanya ${ }^{1}$, M. P. Brundha ${ }^{2}$}

'Saveetha Dental College, Saveetha Institute of Medical and Technical Sciences, Saveetha University, Chennai-77, India; ' Associate Professor, Department of Pathology, Saveetha Dental College, Saveetha Institute of Medical and Technical Sciences, Saveetha University, Chennai-77, India.

\section{ABSTRACT}

Introduction: Immunopathogenesis is the process of the development of a disease that involves immune response or immune system. The focus of the study is basically on the understanding of control and management along with the role-play of host immune responses and the pathogenesis of the microorganism. Coronavirus (CoV) is a large family of viruses which will lead to mild to severe illness, with symptoms most commonly cough, cold, and fever. The severe forms include Middle East Respiratory Syndrome (MERS-CoV) and Severe Acute Respiratory Syndrome (SARS-CoV). The worldwide pandemic COVID-19 was started in Wuhan city. Wuhan city, located in the Hubei province has a huge market called Huanan Seafood market housing numerous non-vegetarian foods which has now become the place where the pandemic started. A new strain of the virus that had not been earlier detected in humans is the Novel coronavirus (nCoV). These ranges of viruses are known to be zoonotic in nature, which means they can be easily transmitted between animals and human patients. The significant challenge faced with these viruses is their evolutionary nature.

Materials and Methods: This is a review article wherein various articles were searched through search engines like Google Scholar and Pubmed using keywords like pathogenesis of COVID-19, immune mechanism of COVID-19, the role of TNF-Alpha, interferons, and diagnosis of COVID-19. Over 50 articles were collected and reviewed thoroughly.

Results and Discussion: The $\mathrm{nCoV}$ is made up of a special protein called the glycosylated protein, which is also called the Spike protein or S protein. It plays a vital role in allowing the entry of viruses into the host cell. The spike protein is a large type 1 transmembrane protein that contains a range of 1160 amino acids. Spike protein is a trimeric class one fusion protein that exists in a metadata level perfusion. The ectodomain of all coronaviruses is known to share the same organization in two domains: an $\mathrm{N}$-terminal domain called S1 that is responsible for receptor binding action and a C terminal S2 domain which is responsible for fusion. This review will give details of the molecular immunopathogenesis of COVID-19.

Key Words: Immunopathogenesis, Pathogenesis of COVID-19, Diagnosis of COVID-19, TNF Alpha in COVID-19, Interferons in COVID-19, Growth factors in COVID-19

\section{INTRODUCTION}

In Wuhan city, Hubei Province, the pandemic now known as COVID-19 began. Many cases of pneumonia due to etiology not known were reported in the said place on December 8, 2019, and prevailed ever since ${ }^{1}$. Later a novel coronavirus which was named as 2019-nCoV by the World Health Organization was isolated from the throat swab of a person affected by this pathogen and had shown disturbances in the respiratory system ${ }^{2}$. Later on, the Coronavirus study group renamed 2019-nCoV to Severe Acute Respiratory Syndrome Coronavirus-2 (SARS-CoV2). This pathogen is highly contagious and has a high incubation period. The transmission of this pathogen is found out to occur from person to person through droplets and biological fluids, especially respiratory fluids ${ }^{3,4}$.

The clinical manifestations of this pathogen were found to be cough, fever, expectoration among the most common ones. Rare clinical manifestations include decreased oxygen saturation, leukopenia, lymphopenia, and increased value of $\mathrm{C}$ reactive protein. The mentioned symptoms in the patients are seen approximately at a period of 5.2 days, which marks its incubation period. The average time period between the appearance of the symptoms and the time of the patient's death is fourteen days ${ }^{5}$. From the clinical features revealed

\section{Corresponding Author:}

Dr. M.P. Brundha, Associate Professor, Department of Pathology, Saveetha Dental College, Saveetha Institute of Medical and Technical Sciences, Saveetha University, Chennai-77, India; Phone: 9884421482; E-mail: brundha.sdc@saveetha.com

ISSN: 2231-2196 (Print)

Received: 15.08 .2020
ISSN: $0975-5241$ (Online)

Revised: 18.09 .2020
Accepted: 08.10 .2020 
by a CT scan of the chest, unusual findings were seen. Acute respiratory distress syndrome, acute cardiac injury and occurrence of ground-glass opacities which eventually led to death ${ }^{6}$. These are some of the unusual findings seen. There is a special protein present in this pathogen ${ }^{7}$. It is called the spike protein, S protein, or glycosylated protein. It is found that this glycosylated protein is responsible for the entry of the virus. It binds with the cell membrane. This $\mathrm{S}$ protein or the glycosylated protein binds to the cellular receptor ACE2, CD 209L, and DPP4 ${ }^{8}$.

The clinical diagnosis of this pathogen is based on the epidemiological history, the clinical manifestations mentioned earlier, and the auxiliary examinations like CT scan, nucleic acid detection, ELISA, and immune identification technology. The envelope spike glycoprotein has specific receptors like ACE for SARS-CoV and SARS-CoV-2, CD209L which is a $\mathrm{C}$ type let in, also called L-sign for SARS-CoV and DPP which is for MERS-CoV.

This review article is mainly focused on the importance of the pathogenesis of COVID-19. The mechanism of action of this pathogen is a vital key point which will lead the pathway to identify a way to stop its action ${ }^{10}$. Getting a better picture of pathogenesis in a detailed manner will pave the way for finding a better, faster, and convenient diagnosis method ${ }^{11,12}$. This review article also focuses on the mechanism of spike protein which plays the key role in virus entry into the host cell. Reading and discussing in detail about the mentioned topics will ultimately lead to a better and improved treatment plan and may also be a milestone in the invention of drugs that inhibit the action of this virus and also the possible prophylaxis can be found ${ }^{13}$.

Previous researches done on this topic is focused on highlighting the effects and adverse effects of the highly pathogenic SARS-CoV-2 that appeared in December 2019 which could even cause death; its role in leading to damaged lungs and when combined with imbalanced immune responses, it may lead to pneumonia. It also highlights the significance of RT-PCR and CT scans in the diagnosis of SARS-CoV-2 infection and also the effect of drugs. Another article discusses the genetics and rapid genomic sequencing along with advanced vaccine technology.

The aim of this study is to find the molecular immune pathogenesis and diagnosis of COVID-19 which will lead to better treatment of the patients with this disease ${ }^{14,15}$.

This review is done with research articles that were searched from various search engines. Data collection was done and information was retrieved by searching keywords such as COVID-19, diagnosis, immunology, and immunopathogenesis. A total of 27 articles were reviewed. The inclusion criteria of this review article include articles related to the pathogenesis of COVID-19, immunology of COVID-19, di- agnosis of COVID-19, the role of TNF- $\alpha$ in COVID-19, and role of various growth factors that are involved and responsible for the COVID lesions. Other articles related to various other categories of coronavirus were considered under exclusion criteria. The period of duration of the articles considered is from 2005 to 2020 which is fifteen years. All the data were thoroughly analyzed to conclude about the molecular immunopathogenesis and diagnosis of COVID-19.

\section{IMMUNOPATHOGENESIS AND DIAGNOSIS OF COVID-19}

\section{Pathogenesis of COVID in Oral Cavity}

When affected with the pathogen SARS-COV-2, being suffering from COVID-19, there will be a high overload of this pathogen in the oropharynx and mucous membrane. Our oral cavity is in direct association with the evolutionary processes involved with the pathogen SARS COV 2. It also comes through contact from the inhalation process ${ }^{16}$. These inhaled viruses will be focused on binding to the epithelial cells of the host, mainly in the nasal cavity and then the oral cavity. Then the replication process begins. In the cell membrane, the binding activity of the virus to the host occurs with the help of a special glycosylated protein called the spike protein or the S- protein. This protein plays a vital role in viral entry. This glycosylated protein will find its entry into the host cell and it is done through the structured rearrangement made by this S-protein ${ }^{17}$.

To find the presence of this pathogen, throat swabs and nasal swabs are taken with appropriate protection measures to prevent the spread of the disease ${ }^{18}$. A highly specific and sensitive laboratory diagnosis is necessary to control the fastevolving coronavirus. PCR assays are proven useful which targets the RNA dependent RNA polymerase ${ }^{19}$.

\section{Pathogenesis of COVID in Lungs}

The deadly pathogen SARS-CoV-2 is highly macrophagetropic. It is also found with noticeable aberrant cytokines or chemokine expression and is also characterized by lymphocyte depletion. In the lungs, severe damages are caused by these pathogens. HCoV-2293 and H-CoV-NL63 are the important cytokines that are related and elevated during lung injury due to SARS-CoV-2. In coronavirus, the spike protein is a significant determinant in virus entry and it binds to the cellular receptors ACe2, CD209L, and DPP-4. Increased leukocyte and increased amount of cytokines will promote severity. Lung pneumocytes are held as the primary targets ${ }^{20}$.

The most common clinical manifestation seen in COVID-19 is respiratory problems. It was also once recognized as pneumonia before identifying the etiology of the disease. Lungs are affected during the course of this pathogen infestation 
and pneumonia may occur as a result of exaggeration in the immune response. The diagnosis measures include RT-PCR and CT scans ${ }^{21}$.

\section{Role of TNF Alpha in COVID}

The characteristic feature of TNF alpha is that it is quickly released and that it initiates inflammatory reactions ${ }^{22}$. Antitumor Necrosis Factor along with TNF antibodies are used for more than 20 years in severe cases of autoimmune inflammatory disorder like Rheumatoid arthritis ${ }^{23}$, inflammatory bowel disease or ankylosing spondylitis. COVID-19 patients should have proper management of pro-inflammatory cytokines with the inclusion of IL-1, IL-6, TNF, and interferon- $\gamma$ in their bloodstream. TNF alpha is also known for its repression action in biological activity ${ }^{24}$. A single infusion of the anti-TNF antibody will be able to tone down some of the activity that occurs during the inflammatory reaction of the lung ${ }^{5}$. TNF alpha also acts as a valid target for diseases related to inflammation.

Researchers are open to any acceptable safe treatment options to get rid of this many life-risking coronaviruses to reduce the death rate. One of such measures taken into consideration is the use of anti-TNF alpha in the treatment of COVID-19 ${ }^{25}$. From the anti-TNF Alpha treatment done so far, there have not been any safety hazards reported. So, it is also established that this kind of treatment does not aggravate any bacterial or fungal superinfection due to immune suppression. This anti-TNF alpha treatment should be taken as early as possible within the infection to get good results ${ }^{26}$.

\section{Role of Interferons in COVID}

Interferons and cytokines primarily function as signal carries in between the cells. Interferons, which the host cells release, are actively involved in activation, balancing, and immunological response. Interferons downstream signaling, signals the decreased immunological response and leads to proliferation and apoptosis of the cell. Type I interferon can be the drug of treatment due to its wide antiviral activity. Type-I IFN has been made of ubiquitous alpha and beta subtype plasmacytoid dendritic cells. It also has the property to induce phosphorylation, make changes in transcriptional factors, and cause immune modulation ${ }^{26,27}$.

According to some studies, interferon treatment has been moderately effective against SARS-CoV and MERS-CoV ${ }^{13}$. 2019 Novel coronavirus has been a bit more sensitive when compared to other coronaviruses when it comes to interferons. Among other interferons, IFN- $\beta$ appears to be the most fitted for the treatment of coronavirus ${ }^{28}$. Now a warrant is given for treatment based on interferon for this pathogen. It is also to be taken into consideration that this interferonbased treatment should be performed on patients at the early stage of the virus manifestation.

\section{Role of FGF, VEGF, and other Growth Factors in COVID Lesions}

Growth factors are a group of proteins that stimulate growth only in specific tissues. Its primary function is to promote cell division and lead in cell differentiation ${ }^{29}$. The role of nASX will enhance immune response and be used in inflammatory therapy. Some growth factors like VEGF, PDGF, and IVIG have an important role in the modulation of cytokines in COVID-19. When there is an increased amount of coronavirus, growth factors will reduce the immune. Inflammatory cytokine storms are common in patients with severe COVID-19 ${ }^{30,31}$.

The role of Interleukin- 6 in the pathogenesis of COVID-19, SARS-CoV-2 has been established with the proper evidence. This Interleukin-6 works in two pathways: the classic pathway - which is the anti-inflammatory pathway and the transsignaling pathway which is also called the pro-inflammatory pathway. It's also proven that SGP130Fc is able to inhibit the Interleukin 6 trans-signalling or pro-inflammatory pathway in COVID-19. The inhibitory action of the STAT pathway which is being activated by IL6 is done by Barcitinib and Ruxolitinib ${ }^{32}$.

A comparatively higher rate of mortality is seen in SARSCoV-1, SARS-CoV-2, and MERS-CoV. The reason found out behind this is that it's due to the availability of Cytokines that cause the cytokine storm. So to completely overcome this virus, targeting the pathogen alone will not be enough, the associated inflammatory action caused by the cytokines should also be taken care of in order to get fully recovered ${ }^{33}$.

\section{CONCLUSION}

COVID 2019 continues to spread as a worldwide pandemic even after so many lockdowns and other various precautionary steps taken by the Government and people. During such terror causing a pandemic, it is necessary to try already existing antiviral drugs and medications in addition to doing research and developing new drugs. Adalimumab can play a possible therapeutic role, which is a TNF alpha based drug. A timely anti-inflammation treatment at the right window time is of pivotal importance. Focusing only on the pathogen will not be enough to overcome the virus, so along with that, the inflammatory action by the cytokines should also be monitored. Various treatment methods like plasma therapy and early diagnosis of the disease could be very helpful. This review highlights the role of TNF alpha interferons and other growth factors which is necessary for better diagnosis and treatment of COVID-19. This review article gives a clear insight into the immunopathogenesis and diagnosis of COVID-19 and allows for future betterment. 


\section{ACKNOWLEDGMENT}

Authors acknowledge the immense help received from the scholars whose articles are cited and included in references to this manuscript. The authors are also grateful to authors / editors / publishers of all those articles, journals, and books from which the literature for this article has been reviewed and discussed.

\section{Conflict of Interest: Nil}

\section{Source of Funding: Nil}

\section{REFERENCES}

1. Xu Z, Shi L, Wang Y, Zhang J, Huang L, Zhang C, et al. Pathological findings of COVID-19 associated with acute respiratory distress syndrome. Lancet Respir Med. 2020 Apr;8(4):420-2.

2. Timothy CN, Samyuktha PS, Brundha MP. Dental pulp Stem Cells in Regenerative Medicine - A Literature Review. Research Journal of Pharmacy and Technology. 2019;12(8):4052-6.

3. Harsha L, Brundha MP. Prevalence of Dental Developmental Anomalies among Men and Women and its Psychological Effect in a Given Population. Journal of Pharmaceutical Sciences and Research. 2017;9(6):869-73.

4. Hannah R, Ramani P, Brundha MP, Herald. J. Sherlin, Ranjith G, Ramasubramanian A, et al. Liquid Paraffin as a Rehydrant for Air Dried Buccal Smear [Internet]. Vol. 12, Research Journal of Pharmacy and Technology. 2019. p. 1197. Available from: http:// dx.doi.org/10.5958/0974-360x.2019.00199.9

5. Boccanegra B, Verhaart IEC, Cappellari O, Vroom E, De Luca A. Safety issues and harmful pharmacological interactions of nutritional supplements in Duchenne muscular dystrophy: considerations for Standard of Care and emerging virus outbreaks. Pharmacol Res. 2020 May 30;158:104917.

6. Shreya S, Brundha MP. Alteration of Haemoglobin Value in Relation to Age, Sex and Dental Diseases-A Retrospective Correlation Study [Internet]. Vol. 10, Research Journal of Pharmacy and Technology. 2017. p. 1363. Available from: http://dx.doi. org/10.5958/0974-360x.2017.00241.4

7. Preethikaa S, Brundha MP. Awareness of diabetes mellitus among general population [Internet]. Vol. 11, Research Journal of Pharmacy and Technology. 2018. p. 1825. Available from: http://dx.doi.org/10.5958/0974-360x.2018.00339.6

8. Sugiyama S, Tanaka R, Hayashi H, Izumi K, Nishie W, Aoyama Y. Acquired Haemophilia A in DPP4 Inhibitor-induced Bullous Pemphigoid as Immune Reconstitution Syndrome. Acta Derm Venereol [Internet]. 2020 Jun 3; Available from: http://dx.doi. org/10.2340/00015555-3539

9. Zehra Z, Luthra M, Siddiqui SM, Shamsi A, Gaur N, Islam A. Corona virus versus existence of human on the earth: A computational and biophysical approach. Int J Biol Macromol [Internet]. 2020 Jun 5; Available from: http://dx.doi.org/10.1016/j. ijbiomac.2020.06.007

10. Prashaanthi N, Brundha MP. A Comparative Study between Popplet Notes and Conventional Notes for Learning Pathology [Internet]. Vol. 11, Research Journal of Pharmacy and Technology. 2018. p. 175. Available from: http://dx.doi.org/10.5958/0974360x.2018.00032.x

11. Kalaiselvi R, Brundha MP. Prevalence of hysterectomy in South Indian population [Internet]. Vol. 9, Research Journal of Phar- macy and Technology. 2016. p. 1941. Available from: http:// dx.doi.org/10.5958/0974-360x.2016.00398.x

12. Mp B, Brundha MP, Nallaswamy D. Hide and seek in pathology- A research on game-based histopathology learning [Internet]. Vol. 10, International Journal of Research in Pharmaceutical Sciences. 2019. p. 1410-4. Available from: http://dx.doi. org/10.26452/ijrps.v10i2.606

13. Brundha MP, Pathmashri VP, Sundari S. Quantitative Changes of Red Blood cells in Cancer Patients under Palliative Radiotherapy-A Retrospective Study. Research Journal of Pharmacy and Technology. 2019;12(2):687-92.

14. Bokadia GS, Sneha. Bokadia G, Brundha MP, Ariga P. Current knowledge about lung cancer amongmiddleaged non medical males a questionnaire based survey [Internet]. Vol. 11, Research Journal of Pharmacy and Technology. 2018. p. 2565. Available from: http://dx.doi.org/10.5958/0974-360x.2018.00474.2

15. Brundha MP. A Comparative Study-The Role of Skin and Nerve Biopsy in Hansen's Disease. Res J Pharm Biol Chem Sci. 2015;7(10):837.

16. John DA, Brundha MP. Awareness of Vitamin A Deficiency among Middle Aged Men-Research. Vitamins \& Minerals. 2016;5(2):144.

17. Shenoy PB, Brundha MP. Awareness of polycystic ovarian disease among females of age group 18-30 years. Res J Pharm Biol Chem Sci. 2016;8(8):813.

18. Ravichandran H, Brundha MP. Awareness about personal protective equipments in hospital workers (sweepers and cleaners). International Journal of Pharmaceutical Sciences Review and Research. 2016;40(1):28-9.

19. Nefedchenko AV, Koteneva SV, Glotova TI, Glotov AG. [Detection of bovine pestiviruses by a multiplex real-time polymerase chain reaction.]. Vopr Virusol. 2020;65(2):95-102.

20. Albasanz-Puig A, Rodríguez-Pardo D, Pigrau C, Lung M, Roldan E, Corona PS, et al. Necrotizing fasciitis in haematological patients: a different scenario. Ann Hematol [Internet]. 2020 May 12; Available from: http://dx.doi.org/10.1007/s00277-02004061-y

21. Balaji S, Brundha MP, Path DNB. Awareness of About Breast Cancer among Dental Surgeons. Res J Pharm Biol Chem Sci. 2016;8(8):797.

22. Shin A, Park EH, Dong Y-H, Ha Y-J, Lee YJ, Lee EB, et al. Comparative risk of osteoporotic fracture among patients with rheumatoid arthritis receiving TNF inhibitors versus other biologics: a cohort study. Osteoporos Int [Internet]. 2020 Jun 8; Available from: http://dx.doi.org/10.1007/s00198-020-05488-9

23. Ferdioz J, Brundha MP. Awareness of stye. International Journal of Pharmaceutical Sciences Review and Research. 2016 Jan 1;40(1):30-2.

24. Kumar MDA, Ashok Kumar MD, Brundha MP. Awareness about nocturia-A questionnaire survey [Internet]. Vol. 9, Research Journal of Pharmacy and Technology. 2016. p. 1707. Available from: http://dx.doi.org/10.5958/0974-360x.2016.00344.9

25. Shu H, Wang M, Song M, Sun Y, Shen X, Zhang J, et al. Acute nicotine treatment alleviates LPS-induced impairment of fear memory reconsolidation through AMPK activation and CRTC1 upregulation in hippocampus. Int J Neuropsychopharmacol [Internet]. 2020 Jun 9; Available from: http://dx.doi.org/10.1093/ ijnp/pyaa043

26. Swetha S, Brundha MP. Analysis of knowledge about the hospital warning symbols among the postgraduate dental studentsA comparative study [Internet]. Vol. 10, Research Journal of Pharmacy and Technology. 2017. p. 975. Available from: http:// dx.doi.org/10.5958/0974-360x.2017.00177.9 
27. Saivignesh S, Brundha MP. Myeloid sarcoma. International Journal of Clinicopathological Correlation. 2019 Jul 1;3(2):41.

28. Wu S-F, Xia L, Shi X-D, Dai Y-J, Zhang W-N, Zhao J-M, et al. RIG-I regulates myeloid differentiation by promoting TRIM25-mediated ISGylation. Proc Natl Acad Sci U S A [Internet]. 2020 Jun 8; Available from: http://dx.doi.org/10.1073/ pnas. 1918596117

29. Midde HS, Priyadarssini M, Rajappa M, Munisamy M, Mohan Raj PS, Singh S, et al. Interleukin-9 serves as a key link between systemic inflammation and angiogenesis in psoriasis. Clin Exp Dermatol [Internet]. 2020 Jun 9; Available from: http://dx.doi. org/10.1111/ced.14335

30. Brundha MP, Haritha PS. Awareness of dengue fever among the parents of children coming to the dental outpatient department - A questionnaire study [Internet]. Vol. 3, International Journal of Clinicopathological Correlation. 2019. p. 60. Available from: http://dx.doi.org/10.4103/ijcpc.ijcpc_14_19
31. Levy GA, Talbot PJ. Corona- and Related Viruses: Current Concepts in Molecular Biology and Pathogenesis. Springer Science \& Business Media; 2012. $615 \mathrm{p}$.

32. Modemann F, Ayuk F, Wolschke C, Christopeit M, Janson D, von Pein U-M, et al. Ruxolitinib plus extracorporeal photopheresis (ECP) for steroid refractory acute graft-versus-host disease of lower GI-tract after allogeneic stem cell transplantation leads to increased regulatory T cell level. Bone Marrow Transplant [Internet]. 2020 May 23; Available from: http://dx.doi.org/10.1038/ s41409-020-0952-Z

33. Jain R, Ajay SS, Anudeep TC, Shetty DU, Jeyaraman M, Chawla $\mathrm{A}$, et al. Current consensus on drugs and biologics against NCOVID-19--a systematic review. Int J Curr Res Rev [Internet]. 2020;12(9). Available from: https://covid19.elsevierpure.com/ en/publications/current-consensus-on-drugs-and-biologicsagainst-ncovid-19-a-syst. 